\title{
A Retrospective Study of Medico-legal Cases Coming to a Tertiary Care Hospital of Malwa Region of Punjab
}

\author{
Ashwini Kumar' ${ }^{1}$ Rajiv Joshi \\ ${ }^{1}$ Associate Professor, ${ }^{2}$ Professor and Head, Department of Forensic Medicine and Toxicology, \\ Guru Gobind Singh Medical College \& Hospital, Faridkot, Punjab
}

\begin{abstract}
Background: Number of person suffering from some kind of illness is increasing day by day. In addition to the individuals suffering from various disease, person with medico-legal injuries or complaints are also admitted in the hospital. A hospital is a place where a patient gets required treatment, undergoes various investigations, procedures and medico-legal formalities when required. In a tertiary care hospital, Emergency Medical Officer is the first doctor to attend the patient. In any case first and foremost duty of a doctor is to save the life of patient. After providing the first aid and following the treatment protocol another duty is to do all medico-legal formalities like issuing Medico-legal reports and sending police information etc in a police case. A medico-legal case is a case where a patient has some assault injuries or having some complaint where a doctor thinks that some kind of information to police is required in the case.
\end{abstract}

Aims and Objectives: To prepare and evaluate complete demographic profile of medico-legal cases admitted at our tertiary care hospital.

Materials and Method: A one and half year retrospective study was conducted in department of Forensic Medicine at G.G.S. Medical College, Faridkot. This study was conducted on cases that came during the period under study i.e. from $1^{\text {st }}$ January 2017 to $30^{\text {th }}$ June 2018.

Results: A total of 1850 medico-legal cases got registered in the emergency during the period under study. Out of these, medico-legal reports were prepared in 1510 cases. Majority of cases in which MLR was issued were of assault followed by road traffic accident. Males dominated the females and commonest age group affected was 21-30 years in our study. Majority of victims got admitted in Surgery department followed by Orthopedics and Neurosurgery department. Most victims came during period from 8PM to 8AM. Maximum number of cases reported in months of summers than winters. Most of the victims were of rural background.

Keywords: Medico-legal case, Casualty, Tertiary Care, Assault.

\section{Introduction}

A doctor working in a government hospital or even in a private hospital has to perform duties which

\footnotetext{
Corresponding Author: Ashwini Kumar

Associate Professor, Department of Forensic Medicine and Toxicology, Guru Gobind Singh Medical College \& Hospital, Faridkot, Punjab e-mail: drashwinifmt@gmail.com
}

can be medical, surgical or medico-legal etc. A tertiary care hospital is a hospital that provides tertiary care, which is health care from specialists in a large hospital after referral from primary care and secondary care. A medico-legal case is a case of injury or having some complaint where a doctor after taking history and clinical examination of the patient thinks that some investigations by law enforcing agencies are essential so as to fix responsibility regarding the case. ${ }^{1}$ It is classified as cases related to the crime against the human body like assaults, rape, burns, poisoning etc. Injury is defined under section 44 IPC as "any harm whatever illegally 
caused to any person, in body, mind, reputation or property". ${ }^{2}$ Profiling of Medico legal cases is an integral aspect for the prevention of preventable causalities in future and to study the crime rate in area. ${ }^{3}$

\section{Materials and Methodology}

A one and half year retrospective study was conducted in department of Forensic Medicine and Toxicology at G.G.S. Medical College, Faridkot. This study was conducted on cases that came during the period under study i.e. from $1^{\text {st }}$ January 2017 to $30^{\text {th }}$ June 2018. Information regarding the date, time and place of the incident, age, gender and place of residence of the victims, time of admission etc was gathered from the available records. The relevant details were analyzed and tabulated by taking various parameters like age, sex, time of admission, cause of MLC etc. for obtaining observations.
Inclusion Criteria: This study included only those cases for which Medico-legal report was issued either on arrival or on request later on.

Exclusion Criteria: Those cases in which Medicolegal report was not issued or those went LAMA/referred to other hospitals were excluded from the study. Cases in which consent was not given or in which MLR was deferred due to unconsciousness or serious condition of victim were also excluded from our study.

Observations: A total of 1850 medico-legal cases got registered in the emergency during the period under study. Out of these, medico-legal reports were prepared in 1510 cases. Majority of cases in which MLR was issued were of assault followed by road traffic accident. (Table 1).

Table 1: Type of Cases

\begin{tabular}{|l|c|c|}
\hline Category & Number of Cases & Percentage \\
\hline Assault & 1035 & 68.5 \\
\hline Road side Accident & 325 & 21.5 \\
\hline Sexual Assault & 50 & 03.3 \\
\hline Others & 100 & 06.7 \\
\hline
\end{tabular}

In our study Males dominated the females. The overall male to female ratio of the cases was $2.8: 1$. The commonest age group affected was 21-30 years for both male and female victims followed by 31-40 age groups. (Table 2).

Table 2: Age and gender-wise distribution of cases

\begin{tabular}{|l|c|c|c|c|c|c|}
\hline \multirow{2}{*}{ Age (in years) } & \multicolumn{2}{|c|}{ Male } & \multicolumn{2}{c|}{ Female } & \multicolumn{2}{c|}{ Total } \\
\cline { 2 - 7 } & Number & \%age & Number & \%age & Number & \%age \\
\hline $00-10$ & 025 & 2.3 & 10 & 2.5 & 35 & 2.3 \\
\hline $11-20$ & 130 & 11.7 & 55 & 13.75 & 185 & 12.3 \\
\hline $21-30$ & 430 & 38.7 & 124 & 31 & 554 & 36.7 \\
\hline $31-40$ & 185 & 16.7 & 74 & 18.5 & 259 & 17.1 \\
\hline $41-50$ & 170 & 15.3 & 67 & 16.75 & 237 & 15.7 \\
\hline$>50$ & 170 & 15.3 & 70 & 17.5 & 240 & 15.9 \\
\hline Total & $\mathbf{1 1 0}$ & $\mathbf{1 0 0}$ & $\mathbf{4 0 0}$ & $\mathbf{1 0 0}$ & $\mathbf{1 5 1 0}$ & $\mathbf{1 0 0}$ \\
\hline
\end{tabular}

Most of the victims were of rural background. Most of the male victims were of rural background. The overall male ratio of rural to urban area was 1.7:1. Majority of female victims also belong to rural background. The overall female ratio being 1.5:1.(Table 3). 
Table 3: Rural/Urban background

\begin{tabular}{|c|c|c|c|c|c|c|}
\hline \multirow{2}{*}{ Background } & \multicolumn{2}{|c|}{ Male } & \multicolumn{2}{|c|}{ Female } & \multicolumn{2}{|c|}{ Total } \\
\hline & No. & $\%$ & No. & $\%$ & No. & $\%$ \\
\hline Rural & 700 & 63 & 215 & 53.8 & 915 & 60.6 \\
\hline Urban & 410 & 37 & 185 & 46.2 & 595 & 39.4 \\
\hline Total & 1110 & 100 & 400 & 100 & 1510 & 100 \\
\hline
\end{tabular}

Majority of victims came during period from 8PM to 8 AM. (Table 4).

Table 4: Time of Arrival

\begin{tabular}{|l|c|c|}
\hline Time & No. of Cases & Percentage \\
\hline 08 AM to 02 PM & 400 & 26.4 \\
\hline 02 PM to 08 PM & 495 & 32.8 \\
\hline 08 PM to 08 AM & 615 & 40.8 \\
\hline
\end{tabular}

Majority of victims were admitted in Surgery department followed by Orthopedics and Neurosurgery department. (Table 5).

Table 5: Admitted in Department

\begin{tabular}{|l|c|c|}
\hline Name of Department & No. of Cases & Percentage \\
\hline Surgery & 575 & 38 \\
\hline Orthopedics & 475 & 31 \\
\hline Neurosurgery & 360 & 24 \\
\hline Others & 100 & 07 \\
\hline
\end{tabular}

Maximum number of cases reported in summer months than winters. (Table 6).

Table 6: Month Wise Distribution

\begin{tabular}{|l|c|c|}
\hline Name of Month & Number of Cases & Percentage \\
\hline January-March & 120 & 08 \\
\hline April-June & 590 & 39 \\
\hline July-September & 750 & 49 \\
\hline October-December & 050 & 04 \\
\hline
\end{tabular}

\section{Discussion}

In the present Study Medico-Legal reports were issued in 1510 cases. It was observed that most of the cases were of Assaults followed by Road Side Accident (RSA). This may be due to the reason that assault victims are keener for Medico-legal reporting than the RSA cases. Garg Vishal etal reported in his study that RTA was highest. ${ }^{4}$ SN Hussainietal reported that Burns constituted majority of MLC. ${ }^{5}$ Majority of cases belong to age group of 21-30 years, being the most active phase of life. This age group is more prone to go for outdoor activities and more prone for assault and accidents. Another reason for RSA is proximity of National highway to our college. Same was also reported by SN Hussainietal. ${ }^{5}$ In our study it was observed that majority of the victims $(40.8 \%)$ reported to casualty in the evening to night period followed by afternoon period as people becomes more prone to assault and accidents due to more recreational activities and parties during that period. Garg Vishal etal reported that the majority of the incidences occur between 1601 to 2000 hours (33.5\%) 
followed by 1201 to 1600 hours (20.9\%) and 2001 to 2400 hours (19.4\%). ${ }^{4}$ Maximum cases were admitted were in the month of July to September (49\%) followed by months of April to June (39\%). Garg Vishal etal reported in his study that maximum cases 92 (11.7\%) were admitted in the month of September and 252 (32.1\%) cases during July to September (monsoons). ${ }^{4}$ Present study shows maximum number of victim were males $(73 \%)$ as compared to females $(27 \%)$ as they are more active member of a family and still the main bread earners of the family as also reported by other various authors. ${ }^{6-11}$

\section{Conclusion}

The casualty department of any hospital not only gives treatment to the patients who reports in emergencies but also carry out legal responsibilities to examine and conduct medico legal cases which in turn puts a lot of burden on the concerned department. The basic principles of preventing injury are education, Law enforcement, pre-hospital care and the evaluation. The doctors who are involved in treatment of such medicolegal cases need to be more trained and skilled in this field.Also due to increase in accidents and violence cases, hospitals have the need for round the clock availability of such medico-legal experts in sufficient number to deal effectively with such cases to better serve judicial purpose.

Ethical Clearance: Taken from Institutional Ethics Committee.

Source of Funding: Nil

Conflict of Interest: Nil

\section{References}

1. Dogra TD, Rudra A. Lyon's Medical Jurisprudence \& Toxicology. 11th Ed. Delhi Law House. 2007:367.
2. Justice YV Chandrachud and VR Manohar. The Indian Penal Code. 31st Enlarged Ed. Wadhwa and Company Nagpur. 2006:228.

3. Malik Y, Chawla R, Sharma G, Malik P, Singh R, Tripathi A. Profile of Medico-legal Cases in Casualty of a Rural Medical College of Haryana. J Indian Acad Forensic Med. 2013; 35 (4):367-8.

4. Garg V, Verma SK. Profile of Medicolegal Cases at Adesh Institute of Medical Sciences and Research, Bthinda, Punjab. J Indian Acad Forensic Med. 2010; 32 (2):150-2.

5. Hussaini SN, Kulkarni CS, Batra AK. Profile of Medico-legal cases coming to casuality of Casuality of Government Medical College, Akola. Journal of Forensic Medicine, science and Law 2013; 22(2)

6. Salgado MSL, Colombage SM. Analysis of fatalities in road accidents. Forensic Sci Int. 1998; 36: 91-6.

7. Sahdev P, Lacqua MJ, Singh B, Dogra TD. Road Traffic fatalities in Delhi: causes, injury patterns and incidence of preventable deaths. Accid Ann Prev. 1994;26: 377-84.

8. Friedman Z, Kungel C, Hiss J, Margovit K, Stein M, Shapira S. The Abbreviated injury scale - a valuable tool for forensic documentation of trauma. Am J Forensic Med Pathol. 1996;17: 233-8.

9. Henriksson EM, Ostrom M, Eriksson A. Preventability of vehicle-related fatalities. AccidAnn Prev. 2001; 33: 467-75.

10. Sharma BR, Harish D, Sharma V, Vij K. Road Traffic accidents-a demographic and topographic analysis. Med Sci Law. 2001;41: 266-74.

11. Jha N, Agrawal CS. Epidemiological Study of Road Traffic Accident Cases: A Study from Eastern Nepal. Regional Health Forum WHO South-East Asia Region. 2004; 8(1): 15. 